\title{
Biopolymeric Materials Used as Nonviral Vectors: A Review
}

\author{
Jailson de Araújo Santos ${ }^{1}$ (D), Daniel Barbosa Liarte ${ }^{2}$, Alessandra Braga Ribeiro ${ }^{3}$, Marcia dos Santos Rizzo ${ }^{1}$, \\ Marcília Pinheiro da Costa ${ }^{1}$, Josy A. Osajima ${ }^{1}$ and Edson C. Silva-Filho ${ }^{1, * \mathbb{C}}$
}

1 Materials Science and Engineering Graduate Program, UFPI, Teresina, 64049-550 Piauí, Brazil; j.santospi@hotmail.com (J.d.A.S.); marciarizzo@ufpi.edu.br (M.d.S.R.); marciliacosta@hotmail.com (M.P.d.C.); josyosajima@ufpi.edu.br (J.A.O.)

2 Biology Department, UFPI, Teresina, 64049-550 Piauí, Brazil; danielbliarte@gmail.com

3 CBQF-Centre of Biotechnology and Fine Chemistry, Associate Laboratory, Faculty of Biotechnology, Catholic University of Portugal, 4169-005 Porto, Portugal; abribeiro@porto.ucp.pt

* Correspondence: edsonfilho@ufpi.edu.br

Citation: Santos, J.d.A.; Liarte, D.B.; Ribeiro, A.B.; Rizzo, M.d.S.; Costa, M.P.d.; Osajima, J.A.; Silva-Filho, E.C. Biopolymeric Materials Used as Nonviral Vectors: A Review. Polysaccharides 2021, 2, 100-109. https://doi.org/10.3390/ polysaccharides 2010007

Academic Editor: Cédric Delattre

Received: 8 January 2021

Accepted: 19 February 2021

Published: 25 February 2021

Publisher's Note: MDPI stays neutral with regard to jurisdictional claims in published maps and institutional affiliations.

\begin{abstract}
Bacterial transformation and gene transfection can be understood as being the results of introducing specific genetic material into cells, resulting in gene expression, and adding a new genetic trait to the host cell. Many studies have been carried out to investigate different types of lipids and cationic polymers as promising nonviral vectors for DNA transfer. The present study aimed to carry out a systematic review on the use of biopolymeric materials as nonviral vectors. The methodology was carried out based on searches of scientific articles and applications for patents published or deposited from 2006 to 2020 in different databases for patents (EPO, USPTO, and INPI) and articles (Scopus, Web of Science, and Scielo). The results showed that there are some deposits of patents regarding the use of chitosan as a gene carrier. The 16 analyzed articles allowed us to infer that the use of biopolymers as nonviral vectors is limited due to the low diversity of biopolymers used for these purposes. It was also observed that the use of different materials as nonviral vectors is based on chemical structure modifications of the material, mainly by the addition of cationic groups. Thus, the use of biopolymers as nonviral vectors is still limited to only a few polysaccharide types, emphasizing the need for further studies involving the use of different biopolymers in processes of gene transfer.
\end{abstract}

Keywords: polysaccharides; cationic biopolymers; genetic vector; synthetic vector

\section{Introduction}

Gene therapy can be defined as treating human disease by transferring genetic material through a vector into specific patient cells. Advances in molecular biology and biotechnology, as well as the conclusion of the Human Genome Project have led to the identification of numerous disease-causing genes. The main purpose of gene therapy is to administer genes to increase the synthesis of naturally occurring proteins, change the expression of existing genes, or produce cytotoxic proteins or activating enzymes-for example, to kill tumor cells or inhibit the proliferation of endothelial cells in the tumor (inhibition of tumor angiogenesis) [1].

The main limiting factor of gene therapy is the rate of gene transfection. In other words, the difficulty of inserting new genes in the cells of intact organisms so that these molecules are incorporated by the cells and can perform their functions efficiently. For some small animals and plants, genes have been introduced in a small number of cells involved in the early embryonic development stage, resulting in the replication of the gene of interest in many or all cells of the adult organism that has been modified [2].

The DNA to be transferred must escape the processes that affect the disposition of macromolecules. These processes include the interaction with blood components, vascular endothelial cells, and absorption by the phagocytic mononuclear system [3]. In addition, 
DNA degradation by nucleases is also a potential obstacle to delivering the gene to the target cell. The two main types of vectors used in gene therapy are based on systems for delivery viral $[4,5]$ or nonviral genes [1-3].

Viral vectors are the most widely used gene delivery system due to the natural activity of viruses that, efficiently, can enter the new target cell, navigate to the cell nucleus, transport their genome from one host cell to another, and start expressing its genome [2,6]. However, the use of viruses in gene therapy could be limited by several factors, such as safety issues raised after the death of a patient during a clinical trial of gene therapy using viral vectors, and the low amount of DNA sequences that can be inserted into the virus genome $[7,8]$. These factors limit large-scale application, and potential problems for patients such as toxicity, immune and inflammatory responses can be observed. The limitations of viral vectors, particularly concerning safety issues, have led to the assessment and development of alternative vectors based on nonviral systems [2].

Regarding the prokaryotic cells, the ability to introduce plasmid DNA molecules into bacterial cells and the subsequent expression of this genetic material in the transformed cell have significantly influenced the development of molecular biology [9].

In some prokaryotic systems, genetic transformation can occur naturally through homologous recombination of free DNA, transduction, and conjugation. However, these natural processes are often unfavorable due to the slow diffusion of hydrophilic DNA entry through the hydrophobic lipid bilayer membrane and the slight electrostatic repulsion between the anionic DNA and the anionic groups of the bilayer membrane. In addition, DNA can undergo hydrolysis or be degraded by any enzymatic process during its transformation course $[10,11]$.

The process of gene transfection consists of introducing specific genes in mammalian and human cells with different purposes, such as the genetic modification of animals or the treatment of inherited diseases. The two perspectives have in common the need to insert modified or corrected information in the cells of the organism to be transformed. Gene transfection covers the field of gene therapy, which can be defined as the treatment of human disease by transferring genetic material using a vector for specific patient cells [1,12].

The genetic material commonly used in the gene transfer techniques, such as the physical methods of electroporation, biobalistics, microinjection, thermal shock, and the chemical method that uses calcium chloride parallel with the thermal shock technique, needs to be manipulated outside the cell before being inserted. Consequently, for an efficient transfer of the target gene to the interior of the cell, it is necessary to use suitable transfer vehicles that protect the DNA against cellular barriers on their way to the nucleus. Cloning vectors are the main tool used for the in vitro incorporation of the target gene into living cells $[13,14]$.

Among the various cloning vectors available for use in the transformation and transfection processes, plasmids are most frequently used. Plasmids are circular DNA molecules, ranging in size from 5000 to 400,000 base pairs (bp), found in bacteria or yeast cells. Some important characteristics are required for a plasmid to be an efficient vector: it must be small and easy to manipulate and replicate; have genes that confer resistance to one or more antibiotics for selection of transformed cells; and contain restriction sites strategically located for the insertion of the DNA of interest [14].

Soni et al. [12] report that many DNA transfer vectors have been developed and cite methods used by other authors involving the encapsulation of DNA in cationic surfactant, the use of copolymer vesicles, viral capsids, protein superstructures, lipid assemblies, polymeric nanocapsules, and structure mesoporous. Although all these techniques are simple and used for the transformation of many species, there are still some limitations to be overcome, such as the difficulty of transferring a copy of the genetic material in a single transformation event, the use of expensive equipment, the segmentation random intracellular and DNA damage due to its unmodified forms.

Many studies have been carried out to investigate different types of lipids and cationic polymers as promising nonviral vectors for DNA transfer $[15,16]$. These cationic materials 
spontaneously form interpolielectrolytic complexes with negatively charged nucleic acids, called lipoplexes and polyplexes, respectively. Among the cationic polysaccharides, cationic dextrans, cationic celluloses, cationic guar, and chitosan have stood out, which are already widely used both in the cosmetics industry and topical drug administration systems [13].

Among natural polymers, cellulose is the most abundant biopolymer in nature, and its cationic derivatives have numerous advantages over different biopolymers, such as biodegradability, recyclability, reproducibility, profitability, and availability in a wide variety of ways. However, the poor solubility of cellulose and its low reactivity makes it challenging to carry out studies with cellulose for biological applications, including studies of bacterial transformation and gene transfection. Thus, the cellulose-derived modification represents a strategy to overcome these limitations, preserving the advantageous characteristics of the biopolymer. Cationic cellulose derivatives are commercial products on a large scale, having many useful characteristics, such as hydrophilicity, biodegradability, and antibacterial properties [17].

In order to choose the best vector that can allow transfection and transformation with high efficiency and quality, it is required to understand the processes involved in the preparation of the vector and the way it interacts with the genetic material. Thus, modified natural biopolymers through quaternization reaction can be tested as synthetic vectors based on their affinity to form a positively charged nanostructure with DNA and allow a higher amount of DNA to get inside the cells (Figure 1).

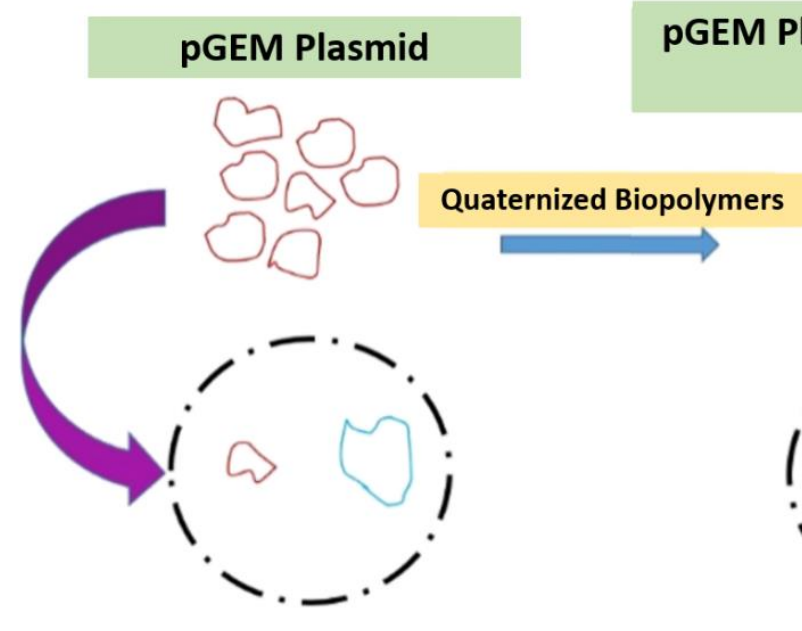

(a)

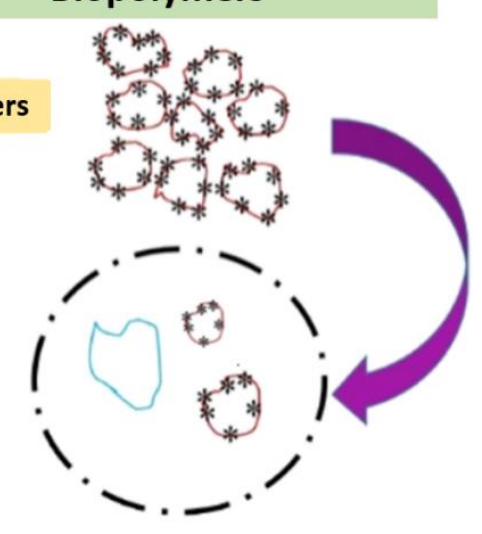

(b)

Figure 1. Scheme illustrating what is expected to occur during the transformation or transfection processes without the use of quaternized biopolymers (a) and within the use of quaternized biopolymers as vectors (b). pGEM $^{\circledR}$ plasmid.

Therefore, the present study aimed at presenting a systematic review of articles and patents on the use of biopolymeric materials as nonviral vectors published and/or deposited between 2006 and 2020.

\section{Materials and Methods}

The prospective review was carried out in August 2020 and was based on an extensive search in different electronic databases.

The prospection of scientific articles was carried out through bibliographical and systematic research in articles. The databases used were Scopus, Web of Science, and Scielo. The search for articles was carried out using the keywords biopolymer, polysaccharide, carbohydrate, gene delivery, and nonviral vector, used separately and in different combinations. To specify the search in the databases, the words were searched for comprising 
the "Title", in the time interval from 2006 to 2020, and, exclusively, publications of regular articles. Review articles and book chapters were left out of the search.

The prospection of patents was carried out in the free online databases European Patent Bank-European Patent Office (EPO), American Bank of Trademarks and PatentsUnited States Patent and Trademark Office (USPTO) and National Institute of Industrial Property (INPI) in Brazil. The search was carried out using the same keywords used, comprising only "Title" in the same time interval. It was used as exclusion criterions: duplicate patents and the ones that do not have the descriptors in the description of use in the patent document.

\section{Results}

\subsection{Scientific Prospecting}

The prospection of articles related to the topic, by using the keywords allowed to determine the database with the largest number of articles published in the area. The result is shown in Table 1.

Table 1. Number of articles published in the Scopus, Web of Science and Scielo databases by time interval.

\begin{tabular}{|c|c|c|c|}
\hline \multicolumn{4}{|c|}{ Published Articles from 2006 to 2020} \\
\hline Keywords & Scopus & $\begin{array}{l}\text { Web of } \\
\text { Science }\end{array}$ & Scielo \\
\hline biopolymer & 2.247 & 1.838 & 31 \\
\hline polysaccharide & 13.179 & 11.203 & 44 \\
\hline carbohydrate & 11.589 & 10.493 & 92 \\
\hline gene delivery & 4.152 & 3.843 & 2 \\
\hline nonviral vector & 204 & 182 & 1 \\
\hline biopolymer and gene delivery & 2 & 1 & 0 \\
\hline biopolymer and nonviral vector & 0 & 0 & 0 \\
\hline polysaccharide and gene delivery & 12 & 11 & 0 \\
\hline polysaccharide and nonviral vector & 1 & 0 & 0 \\
\hline carbohydrate and gene delivery & 7 & 7 & 0 \\
\hline carbohydrate and nonviral vector & 0 & 0 & 0 \\
\hline \multirow{2}{*}{$\begin{array}{l}\text { biopolymer and gene delivery and nonviral vector } \\
\text { polysaccharide and gene delivery and nonviral } \\
\text { vector }\end{array}$} & 0 & 0 & 0 \\
\hline & 0 & 0 & 0 \\
\hline $\begin{array}{c}\text { carbohydrate and gene delivery and nonviral } \\
\text { vector }\end{array}$ & 0 & 0 & 0 \\
\hline TOTAL & 31.393 & 27.578 & 170 \\
\hline
\end{tabular}

Table 1 shows that the database with the largest number of articles published in the area is Scopus, which presented a higher publication number of articles than the other analyzed databases.

After prospecting the articles in the three databases, 15 articles were selected from all articles contained in their titles, the words "gene delivery" and/or "nonviral vector". The articles were chosen based on the material used and the application of the biopolymer. Then, the selected articles were analyzed to verify (1) annual evolution, (2) worldwide distribution, and (3) discussion of the articles.

\subsubsection{Annual Evolution}

The study of the annual evolution of publications in the range from 2006 to 2020 was carried out, as shown in Figure 2.

From the results presented in the graphic, it is possible to observe that using different materials as nonviral vectors is a new area and has been increasingly studied since 2015 according to the number of publications on the content. Among the 16 articles analyzed in this study, it was not chosen articles published from 2017 to 2020; however, from the graph, it was possible to observe a pattern of increasing publications on the topic from 2015. 


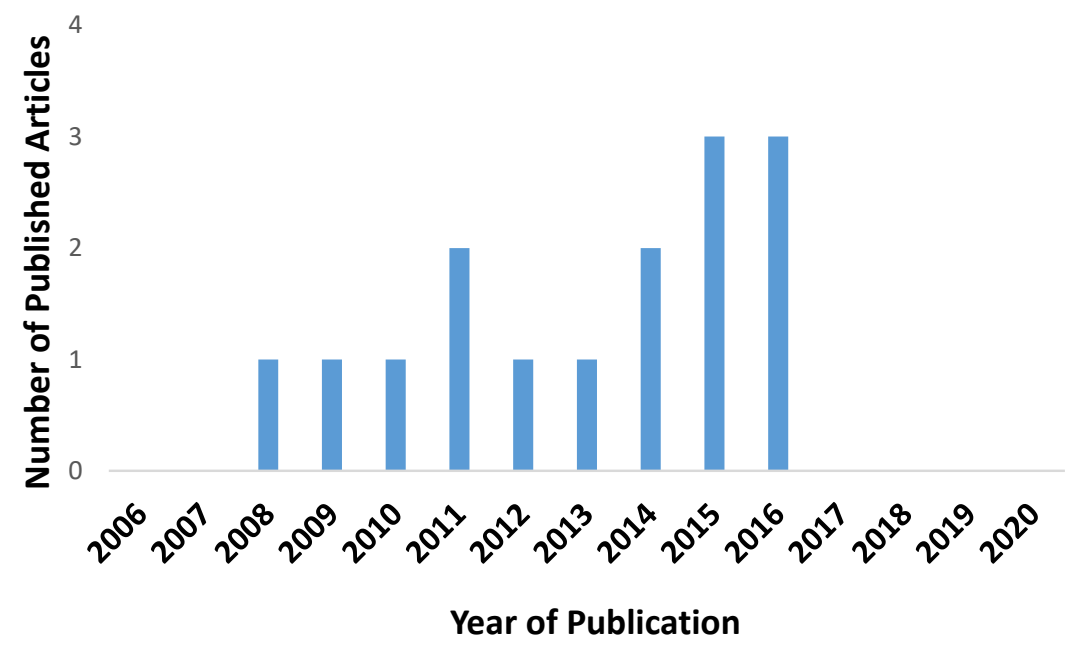

Figure 2. Annual evolution of published articles on the topic from 2006 to 2020.

\subsubsection{Worldwide Distribution}

Regarding the countries that have published the most articles on the topic in recent years, Figure 3 shows the worldwide distributions of articles published. The countries with more publications are China (with four published articles), followed by Japan, Iran and South Korea (all with two published articles), while the other countries presented only one publication.

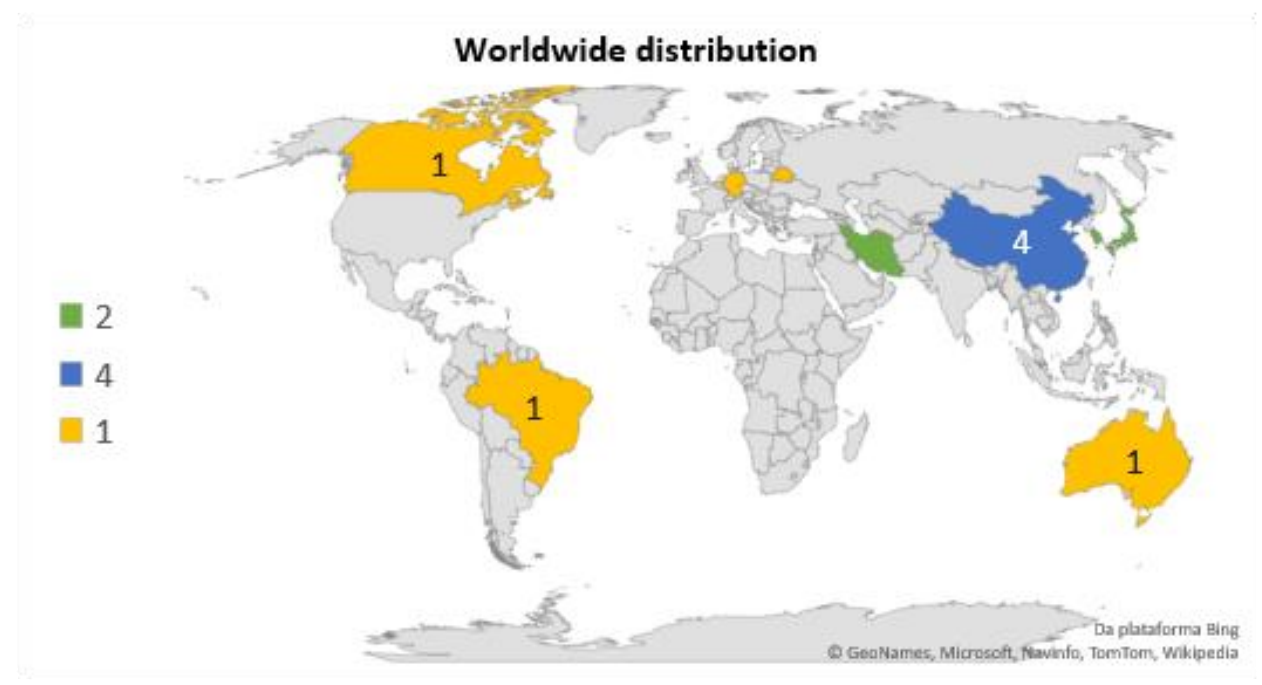

Figure 3. Worldwide distribution of published articles on the topic from 2006 to 2020.

The result obtained can be attributed to the fact that the four countries with the largest number of publications are references in the area of scientific and technological development (S\&T), research, and qualified education [18].

\subsubsection{Discussion of Articles}

The 15 articles describe the effect of different materials used as nonviral vectors in different types of cells in the processes of gene transfection and bacterial transformation, as well as the factors that influence this process, such as the type of material, cytotoxicity, and the rates of transfection and transformation.

Table 2 presents the main factors evaluated in the articles about to the efficiency of gene transfection and bacterial transformation by different biopolymers and polysaccharides derivates: chitosan [19], dextran [20,21], quaternized cellulose [22] and quaternized chitosan [23]. 
Table 2. Evaluation parameters used in the prospecting articles.

\begin{tabular}{|c|c|c|c|}
\hline Material Type & Cytotoxicity & Nonviral Vector Efficiency & References \\
\hline $\begin{array}{l}\text { Chitosan-Polyethyleneimine/DNA } \\
\text { nanoparticles }\end{array}$ & Low & $\begin{array}{l}\text { Significantly enhanced } \\
(p<0.05)\end{array}$ & [19] \\
\hline $\begin{array}{c}\text { Aldehyde and } \varepsilon \text {-poly (L-lysine) dextran } \\
\text { hydrogel }\end{array}$ & Low & Significantly enhanced $(p<0.05)$ & [20] \\
\hline $\begin{array}{l}\text { Dextran-MMA cationic polysaccharide (methyl } \\
\text { methacrylate ester) conjugated to the copolymer } \\
\text { (2-diethylaminoethyl-dextran- } \\
\text { methylmethacrylate) }\end{array}$ & Low & $\begin{array}{l}\text { Significantly enhanced } \\
\qquad(p<0.05)\end{array}$ & [21] \\
\hline Quaternized cellulose & Low & $\begin{array}{l}\text { Significantly enhanced } \\
(p<0.05)\end{array}$ & [22] \\
\hline Quaternized chitosan & High & $\begin{array}{l}\text { Not significantly enhanced } \\
\qquad(p>0.05)\end{array}$ & [23] \\
\hline
\end{tabular}

Other types of substances were used as nonviral vectors such as: plasmid DNA nanostructures with ionic liquid [11], pegylated polyethyleneimine nanoparticles conjugated with folate and galactose [24], cationic liposomes modified with polyallylamine [25], biodegradable polylactic acid-polyethylene glycol-poly (L-lysine) copolymer [26], crotamine [27], poly (oligo-D-arginine) [28], poly (lactic acid-co-glycolic acid) scaffolds [29], polyethyleneimine/pDNA nanocomplexes with anionic hyaluronic acid [30], fourth generation cationic phosphorus (P4) containing dendrimers [31], and monosylated polyethyleneimine [32] All the materials tested on these studies showed low cytotoxicity and enhanced significantly the efficiency $(p<0.05)$. The criteria used to evaluate the transfection efficiency was the " $p$ value": $p<0.05$ was considered "significantly enhanced" and $p>0.05$ "not significantly enhanced".

\subsection{Technological Prospecting}

The analysis of patent filings by base revealed that EPO, in comparison with the USPTO and INPI bases, was the base that received the most deposits related to the studied subject in the investigated time interval. The keywords used in the research showed different results when compared to those obtained for articles, and the data found are shown in Table 3.

Table 3. Total patents deposited on EPO, USPTO and INPI databases between 2006 and 2020.

\begin{tabular}{|c|c|c|c|}
\hline Keywords & EPO & USPTO & INPI \\
\hline biopolymer & 1.110 & 165 & 39 \\
\hline polysaccharide & 7.695 & 387 & 112 \\
\hline carbohydrate & 2.462 & 255 & 84 \\
\hline gene delivery & 670 & 82 & 2 \\
\hline nonviral vector & 35 & 0 & 1 \\
\hline biopolymer and gene delivery & 0 & 0 & 0 \\
\hline biopolymer and nonviral vector & 0 & 0 & 0 \\
\hline polysaccharide and gene delivery & 2 & 0 & 0 \\
\hline polysaccharide and nonviral vector & 1 & 0 & 0 \\
\hline carbohydrate and gene delivery & 0 & 0 & 0 \\
\hline carbohydrate and nonviral vector & 0 & 0 & 0 \\
\hline biopolymer and gene delivery and nonviral vector & 0 & 0 & 0 \\
\hline polysaccharide and gene delivery and nonviral vector & 0 & 0 & 0 \\
\hline carbohydrate and gene delivery and nonviral vector & 0 & 0 & 0 \\
\hline TOTAL & 11.975 & 889 & 238 \\
\hline
\end{tabular}

\section{Discussion}

The analysis of the chosen articles (Table 2) allows us to identify that the principle of using different materials as nonviral vectors for the transfer of genes into target cells consists of modifying the chemical structure of the material, mainly the addition of cationic groups. 
Polyethyleneimine (PEI) is one of the most successful and efficient nonviral gene transfer systems that have been reported to date. In four of the fifteen articles $[19,24,30,32]$, PEI was used as the main polymer modified and used as a vector of gene transport.

In the study of Ghiamkazemi et al. [24], polyethyleneimine (PEI) is described as highly cytotoxic in many cell lines due to its high surface load, non-biodegradability, and non-biocompatibility. To improve the biodegradability of PEI, the authors synthesized a copolymer of PEI with polyethylene glycol conjugated with folic acid and galactose. The synthesized copolymer proved to be non-cytotoxic and with a high rate of gene transfection [24].

Regarding the use of biopolymers to modify PEI, [19] chitosan was used as a PEI modifying agent. The authors synthesized chitosan nanoparticles with PEI called chitosangraft-polyethylenimine $(\mathrm{CP})$ and tested this nonviral vector's efficiency in the transfection process. The CP/DNA nanoparticles' transfection efficiency was affected by the weight ratio of $\mathrm{CP}$ : DNA $(w / w)$. The average cell viability after treatment with $\mathrm{CP} / \mathrm{DNA}$ nanoparticles was over $90 \%$. The authors [19] also compared the transfection efficiency of CP/DNA nanoparticles with that of grafting chitosan CS/DNA nanoparticles, naked pDNA, PEI $(25 \mathrm{kDa}) / \mathrm{DNA}$ nanoparticles, and Lipofectamine TM 2000. The results showed that the CP/DNA complex was similar to that of the Lipofectamine TM 2000, indicating that the biopolymers work similarly to the commercial assays available for transfection [19].

Another requirement to achieve successful transfection is that the bound pDNA must release from complexes: the unpacking of DNA from the polymeric vector is an important and crucial step in the transfection mediated by polymers [26]. Thus, the nonviral vector should chemically interact with the pDNA to form the nanoparticle, but this chemical interaction should be weak enough to release the pDNA in the nucleus to achieve the transfection process aiming. In their study, [19] found the chitosan copolymer binding capability is neither strong nor weak, which may be beneficial for improving transfection efficiency.

The transfection efficiency regards the transport of the pDNA into the nucleus of the target cells. This delivery should be trafficked in order to ensure that the pDNA reaches the cells' nucleus. To investigate the cellular entry path, [19] used the Cy3-labeled pDNA (red marker) and CP/DNA was simultaneously added to both chondrocytes and synoviocytes cells, LysoTracker Green DND-26 was added to label lysosomes, and cells were fixed with PFA at specified intervals. The authors [19] observed that CP was able to carry pDNA inside cells (cytoplasm) within $30 \mathrm{~min}$ to $1 \mathrm{~h}$ after the addition of nanoparticles to the cells. Further, pDNA could be observed inside the nucleus $2 \mathrm{~h}$ post addition of complexes, and a greater pDNA mount could be detected in the nucleus after $4 \mathrm{~h}$. Thus, the author concluded that $\mathrm{CP}$ vectors could efficiently carry the desired gene inside both target cells [19].

Analyzing the cytotoxicity and transfection efficiency of chitosan [19], the authors observed the average cell viability after the treatment with CP/DNA nanoparticles was over $90 \%$, which was much higher than that of PEI ( $25 \mathrm{kDa}) /$ DNA nanoparticles. The transfection efficiency of the $\mathrm{CP} / \mathrm{DNA}$ nanoparticles was dependent on the weight ratio of CP:DNA $(w / w)$. The transfection efficiency of CP/DNA nanoparticles was similar with that of the Lipofectamine ${ }^{\mathrm{TM}}$ 2000, and significantly higher than that of CS/DNA and PEI (25 kDa)/DNA nanoparticles [19].

Two special types of materials used as vectors for gene transfer were observed: in the study carried out by Togo et al. [20], who developed a biodegradable hydrogel composed of $20 \% w / w$ dextran aldehyde and $10 \% w / w \varepsilon$-poly (L-lysine) (ald-dex/PLL); and in the study carried out by Perisic et al. [29], who tested biodegradable poly (lactic acid-co-glycolic acid) (PLGA) scaffolds, clinically used as transient transporters for genetically modified cells. In both studies, a high rate of gene transfection was observed with the use of these materials.

The effect of quaternized cellulose (QC) in gene transfection in 293T cells was analyzed by Song et al. [22]. The authors observed that the cytotoxicity rates were relatively low compared to the PEI and the transfection rates were high. Both the cytotoxicity and the transfection efficiency of the QC/DNA nanostructures increased with the degree of 
substitution (GS) of the QCs. Regarding the binding capability of polycations to pDNA, the authors [22] stated that the polycations could condense pDNA into compact structures and reduces the electrostatic repulsion between DNA and cell surface by neutralizing the negative charge, which facilitates the uptake of the complex to negatively charged cell membrane constituents and, therefore, to a higher rate of uptake. In the study [22], the quaternized cellulose binding capacity was investigated by agarose gel electrophoresis, which allows estimating the particle size and the formation of nanocomplex between the pDNA and the biopolymer. The authors found QCs with a strong binding ability and a higher DS value, which induced higher positive charge density [22].

Cytotoxicity is one of the most common problems with the transfection assay. A major requirement of the polymeric vectors for use in gene therapy is the absence of cytotoxicity. In their study, Song et al. [22] investigated the cytotoxicity of quaternized cellulose in 293T cells by MTT assay, and the $25 \mathrm{kDa}$ PEI was used as the control. The results demonstrated that the cytotoxicity of QCs increased gradually with an increase in the concentrations and DS values due to a higher amount of cationic cellulose damaging the cellular membranes. However, the QCs exhibited much lower cytotoxicity than PEI, the most popular "gold standard" of cationic polymer transfection. The transfection efficiency of QC/DNA complexes was evaluated in 293T cells, and the plasmid pGL-3 DNA was used as the luciferase reporter gene [22]. Song et al. [22] found that the trends of transfection efficiency for the quaternized cellulose complexes was depended on the DS value of QCs, which was attributed to the positively charged surface, allowing an optimal binding of QC with the DNA complexes to cellular membranes. The transfection efficiency was relatively lower than that of PEI; QCs increased the transfection efficiency markedly compared with the naked DNA values (up to 1058-fold). Considering the much lower cytotoxicity than PEI, the authors concluded that QCs could be considered promising nonviral gene carriers in vitro [22].

Regarding the use of materials to increase the efficiency of bacterial transformation, two articles were found [11,33]. These studies investigated the effect of nanostructures of ionic liquid [11] and quaternized chitosan with plasmid DNA on the efficiency of bacterial transformation [23]. The authors observed a low rate of cytotoxicity and a high transformation efficiency rate for the ionic liquid [11]. As for the quaternized chitosan, it was observed an inhibitory effect of the material regarding the bacterial growth, with high cytotoxicity and low transformation efficiency [23].

The results presented in Table 3 show the numbers of filed patents in the databases searched. From these results, it was observed that using the most general words: "biopolymer", "polysaccharide" and "carbohydrate", a large number of deposits were found in all databases, with the largest number of patents filed containing the word "polysaccharide". As more words were added, the number of deposits decreased significantly. This trend can be attributed to the fact that the patents with these words in their titles had the most diverse purposes, and with the specification of the research, the deposits become limited.

For the terms "gene delivery" and "nonviral vector", the number of patent registrations was determined. It was possible to verify that most of the patents contained the term "gene delivery" in the titles, which is a term that covers different types of studies.

It was observed that with the combination of the keywords, no results were found in any of the search bases, except for the terms "polysaccharide and gene delivery" (two deposits) and polysaccharide and nonviral vector (one deposit).

The results showed that there are filed patents regarding the use of the chitosan biopolymer as a nonviral vector for gene transport.

The Chinese patents filed by Oskuee et al. [25] and Li et al. [34] present two inventions that provide methods for the preparation of nonviral polyethyleneimine gene vectors conjugated with chitosan. The vectors showed good biocompatibility and high efficiency of gene transfection, being excellent vectors for gene transfection and perspectives for a wide range of applications. The authors [34] reported that the agarose gel retardation assay, dynamic light scattering, and scanning electron microscopy experiments revealed that in 
the characterization of the obtained product, CHI-g-PEI had a good ability to condense plasmid DNA into spherical nanoparticles in the size range of 200-300 nm. Besides, in the simulated physiological environment, the polymer/pDNA complexes are relatively stable, meanwhile; an efficient release of pDNA was detected in the presence of $25 \mathrm{mM}$ DTT, mimicking the intracellular reductive environment. Therefore, the authors concluded that the bioreducible chitosan-graft-polyethyleneimine CHI-g-PEI copolymer, thus obtained, can be used as a promising nonviral gene carrier due to its excellent properties [34].

Another Chinese patent filed by Chen et al. [35] describes a microenvironment doubleresponse chitosan gene carrier and the preparation method and application of the material. The vector is a polymer obtained from the combination of polyethyleneimine and polyethylene glycol with macromolecular chitosan (SRCS) to obtain a $\mathrm{pH}$-sensitive polymer SRCS-g-PEI-g-PEG. The polymer showed good biocompatibility and high efficiency of gene transfection. The authors described that compared with modifying chitosan (CS), the synthesized CS-g-PEI copolymers showed higher pDNA-binding affinity, which increased with the grafting degree (GD) as shown in Agarose gel electrophoresis. The CS-g-PEI copolymer with a medium GD of $4.5 \%$ conferred the best gene transfection, with the efficiency 44 times of CS and 38 times of PEI-1.8 in HEp-2 cells. The cytotoxicity of CS-g-PEI was tested and found nearly as low as that of CS and much lower than that of PEI [35].

\section{Conclusions}

Regarding the data presented in this review, it can be stated that the use of biopolymers as nonviral vectors is a recent approach. In addition, the number of studies on the topic is limited with a low diversity of biopolymers or polysaccharides derivatives used for these purposes. Therefore, these results highlight the need for further studies involving different biopolymers as nonviral vectors to deliver genes into bacterial and eukaryotic cells.

Author Contributions: J.d.A.S., D.B.L., A.B.R., M.d.S.R., M.P.d.C., J.A.O. and E.C.S.-F., all authors contributed to this study. All authors have read and agreed to the published version of the manuscript.

Funding: This research received no external funding.

Institutional Review Board Statement: Not applicable.

Informed Consent Statement: Not applicable.

Data Availability Statement: Not applicable.

Acknowledgments: The authors thank UFPI, CNPq, CAPES and FAPEPI for structural support.

Conflicts of Interest: The authors declare no conflict of interest.

\section{References}

1. Pack, D.W.; Hoffman, A.S.; Pun, S.; Stayton, P.S. Design and development of polymers for gene delivery. Nat. Rev. 2005, 4, 581-593. [CrossRef] [PubMed]

2. Mansouri, S.; Lavigne, P.; Corsi, K.; Benderdour, M.; Beaumont, E.; Fernandes, J.C. Chitosan-DNA nanoparticles as non-viral vectors in gene therapy: Strategies to improve transfection efficacy. Eur. J. Pharm. Biopharm. 2004, 57, 1-8. [CrossRef]

3. Quong, D.; Neufeld, R.J. DNA protection from extracapsular nucleases, within chitosan or poly-L-lysine-coated alginated beads. Biotechnol. Bioeng. 1998, 60, 124-134. [CrossRef]

4. Ghivizzani, S.C.; Oligino, T.J.; Glorioso, J.C.; Robbins, P.D.; Evans, C. Gene Therapy Approaches for Treating Rheumatoid Arthritis. Clin. Orthop. Relat. Res. 2000, 379, S288-S299. [CrossRef] [PubMed]

5. Marshall, E. FDA Halts All Gene Therapy Trials at Penn. Science 2000, 287, 565-567. [CrossRef] [PubMed]

6. Oligino, T.J.; Yao, Q.; Ghivizzani, S.C.; Robbins, P. Vector systems for gene transfer to joints. Clin. Orthop. 2000, 379, S17-S30. [CrossRef] [PubMed]

7. Somia, N.; Verma, I.M. Gene therapy: Trials and tribulations. Nat. Rev. Genet. 2000, 1, 91-99. [CrossRef] [PubMed]

8. Ferber, D. Gene therapy: Safer and virus-free? Science 2001, 294, 1638-1642. [CrossRef]

9. Singh, M.; Yadav, A.; Ma, X.; Amoah, E. Plasmid DNA transformation in Escherichia coli: Effect of heat shock temperature, duration, and cold incubation of $\mathrm{CaCl} 2$ treated cells. Int. J. Biotechnol. Biochem. 2010, 6, 561-568.

10. Cehovin, A.; Simpson, P.J.; Mcdowell, M.A.; Brown, D.R.; Noschese, R.; Pallett, M.; Brady, J.; Baldwin, G.S.; Lea, S.M.; Matthews, S.J.; et al. Specific DNA recognition mediated by a type IV pilin. Proc. Natl. Acad. Sci. USA 2013, 110, 3065-3070. [CrossRef] [PubMed] 
11. Soni, K.S.; Sampa Sarkar, S.; Mirzadeh, N.; Selvakannan, P.R.; Bhargava, S.K. Self-Assembled Functional Nanostructure of Plasmid DNA with Ionic Liquid [Bmim][PF6]: Enhanced Efficiency in Bacterial Gene Transformation. Langmuir 2015, 31, 4722-4732. [CrossRef] [PubMed]

12. Kaestner, L.; Scholz, A.; Lipp, P. Conceptual and technical aspects of transfection and gene delivery. Bioorg. Med. Chem. Lett. 2015, 25, 1171-1176. [CrossRef]

13. Fayazpour, F.; Lucas, B.; Alvarez-Lorenzo, C.; Sanders, N.N.; Demeester, J.; Smedt, S.C. Physicochemical and Transfection Properties of Cationic Hydroxyethylcellulose/DNA Nanoparticles. Biomacromolecules 2006, 7, 2856-2862. [CrossRef]

14. Calvete, C.L.; Caseiro, M.M.; Souza, C.B. Biotecnologia: Transformação Bacteriana por Método de Choque-Térmico. UNILUS Ensino Pesqui. 2015, 12, 41-53.

15. Brown, M.D.; Schatzlein, A.G.; Uchegbu, I.F. Gene delivery with synthetic (non viral) carriers. Int. J. Pharm. 2001, $23,1-21$. [CrossRef]

16. Wagner, E.; Ogris, M.; Zauner, W. Polylysine-based transfection systems utilizing receptor-mediated delivery. Adv. Drug Deliv. Rev. 1998, 30, 97-113. [PubMed]

17. Sivakumar, B.; Aswathy, R.G.; Nagaoka, Y.; Suzuki, M.; Fukuda, T.; Yoshida, Y.; Maekawa, T.; Sakthikumar, D.N. Multifunctional Carboxymethyl Cellulose-Based Magnetic Nanovector as a Theragnostic System for Folate Receptor Targeted Chemotherapy, Imaging, and Hyperthermia against Cancer. Am. Chem. Soc. 2013, 29, 3453-3466. [CrossRef] [PubMed]

18. Guimarães, J.A. A pesquisa médica e biomédica no Brasil: Comparações com o desempenho científico brasileiro e mundial. Ciênc. Saúde Coletiva 2004, 9, 303-327. [CrossRef]

19. Lu, H.; Dai, Y.; Lv, L.; Zhao, H. Chitosan-Graft-Polyethylenimine/DNA Nanoparticles as Novel Non-Viral Gene Delivery Vectors Targeting Osteoarthritis. PLoS ONE 2014, 9, 12. [CrossRef]

20. Togo, Y.; Takahashi, K.; Saito, K.; Kiso, H.; Huang, B.; Tsukamoto, H.; Hyon, S.-H.; Bessho, K. Aldehyded Dextran and $\varepsilon$-Poly (L-lysine) Hydrogel as Nonviral Gene Carrier. Stem Cells Int. 2013, 13, 5. [CrossRef] [PubMed]

21. Eshita, Y.; Higashihara, J.; Onishi, M.; Mizuno, M.; Yoshida, J.; Takasaki, T.; Kubota, N.; Onishi, Y. Mechanism of the Introduction of Exogenous Genes into Cultured Cells Using DEAE-Dextran-MMA Graft Copolymer as a Non-Viral Gene Carrier. Molecules 2009, 14, 2669-2683. [CrossRef] [PubMed]

22. Song, Y.; Sun, Y.; Zhang, X.; Zhou, J.; Zhang, L. Homogeneous quaternization of cellulose in NaOH/urea aqueous solutions as gene carriers. Biomacromolecules 2008, 9, 2259-2264. [CrossRef] [PubMed]

23. Kim, C.; Saidy, N.R.N.; Fu, R.; Wang, R. Chitosan Inhibits pBR322-AmpR transformation in Escherichia coli DH5 $\alpha$. J. Exp. Microbiol. Immunol. (JEMI) 2015, 15, 1-7.

24. Ghiamkazemi, S.; Amanzadeh, A.; Dinarvand, R.; Rafiee-Tehrani, M.; Amini, M. Synthesis, and Characterization, and Evaluation of Cellular Effects of the FOL-PEG-g-PEI-GAL Nanoparticles as a Potential Non-Viral Vector for Gene Delivery. J. Nanomater. 2010, 10, 10. [CrossRef]

25. Oskuee, R.K.; Mahmoudi, A.; Gholami, L.; Rahmatkhah, A.; Malaekeh-Nikouei, B. Cationic Liposomes Modified with Polyallylamine as a Gene Carrier: Preparation, Characterization and Transfection Efficiency Evaluation. Adv. Pharm. Bul. 2016, 6, 515-520. [CrossRef]

26. Fu, C.; Sun, X.; Liu, D.; Chen, Z.; Lu, Z.; Zhang, N. Biodegradable Tri-Block Copolymer Poly (lactic acid)-poly (ethylene glycol)-poly(L-lysine)(PLA-PEG-PLL) as a Non-Viral Vector to Enhance Gene Transfection. Int. J. Mol. 2011, 12, 1371-1388. [CrossRef]

27. Chen, P.-C.; Hayashi, M.A.F.; Oliveira, E.B.; Karpel, R.L. DNA-Interactive Properties of Crotamine, a Cell-Penetrating Polypeptide and a Potential Drug Carrier. PLoS ONE 2012, 7, 11. [CrossRef]

28. Woo, J.; Bae, S.-H.; Kim, B.; Park, J.S.; Jung, S.; Lee, M.; Kim, Y.-H.; Choi, D. Cardiac Usage of Reducible Poly (oligo-D-arginine) As a Gene Carrier for Vascular Endothelial Growth Factor Expression. PLoS ONE 2015, 10, 11. [CrossRef] [PubMed]

29. Perisic, T.; Zhang, Z.; Foehr, P.; Hopfner, U.; Klutz, K.; Burgkart, R.; Slobodianski, A.; Goeldner, M.; Machens, H.G.; Schilling, A.F. Biodegradable poly (lactic acid-co-glycolic acid) scaffolds as carriers for genetically-modified fibroblasts. PLoS ONE 2017, 12, 16. [CrossRef]

30. Cho, S.-H.; Noh, Y.-W.; Cho, M.Y.; Lim, Y.T. An Electrostatically Self-Assembled Ternary Nanocomplex as a Non-Viral Vector for the Delivery of Plasmid DNA into Human Adipose-Derived Stem Cells. Molecules 2016, 21, 572. [CrossRef]

31. Shcharbin, D.; Dzmitruk, V.; Shakhbazau, A.; Goncharova, N.; Seviaryn, I.; Kosmacheva, S.; Potapnev, M.; Pedziwiatr-Werbicka, E.; Bryszewska, M.; Talabaev, M.; et al. Fourth Generation Phosphorus-Containing Dendrimers: Prospective Drug and Gene Delivery Carrier. Pharmaceutics 2011, 3, 458-473. [CrossRef] [PubMed]

32. Hu, Y.; Xu, B.-H.; Xu, J.-J.; Shou, D.; Gao, J.-Q. Synthesis of Mannosylated Polyethylenimine and Its Potential Application as Cell-Targeting Non-Viral Vector for Gene Therapy. Polymers 2014, 6, 2573-2587. [CrossRef]

33. Kircheis, R.; Wightman, L.; Wagner, E. Design and gene delivery activity of modified polyethylenimines. Adv. Drug Deliv. Rev. 2001, 53, 341-358. [CrossRef]

34. Li, Z.-T.; Guo, J.; Zhang, J.-S.; Zhao, Y.-P. Chitosan-graft-polyethylenimine with improved properties as a potential gene vector. Carbohydr. Polym. 2010, 80, 254-259. [CrossRef]

35. Chen, H.; Cui, S.; Zhao, Y.; Zhang, C.; Zhang, S.; Peng, X. Grafting Chitosan with Polyethylenimine in an Ionic Liquid for Efficient Gene Delivery. PLoS ONE 2015, 10, 1-17. [CrossRef] [PubMed] 